$\overline{\text { REVIEW }}$-Current Perspective-

\title{
Chloride Channels and Their Functional Roles in Smooth Muscle Tone in the Vasculature
}

\author{
Kenji Kitamura* and Jun Yamazaki \\ Department of Pharmacology, Fukuoka Dental College, 2-15-1 Tamura, Sawara-ku, Fukuoka 814-0193, Japan
}

Received December 11, 2000

\begin{abstract}
Although evidence of important contributions by $\mathrm{Cl}^{-}$channels to agonist-induced currents have been reported in vascular smooth muscle cells, the functional roles played by $\mathrm{Cl}^{-}$channels in the smooth muscle contraction and in setting the membrane potential remain essentially obscure. All of the admittedly few papers published have focused on the physiological roles of $\mathrm{Cl}^{-}$channels in the contraction and membrane depolarization elicited by agonists. At present, it seems likely that in vascular cells: a) $\mathrm{Cl}^{-}$ conductance contributes to membrane depolarization, with the subsequent contraction being due to $\mathrm{Ca}^{2+}$ release from the intracellular store sites, and b) $\mathrm{Cl}^{-}$movements through the membrane of the $\mathrm{Ca}^{2+}$ store sites also regulate $\mathrm{Ca}^{2+}$ release and $\mathrm{Ca}^{2+}$ uptake from/into the store sites. As a $\mathrm{Ca}^{2+}$-dependent $\mathrm{Cl}^{-}$current is most easily demonstrated under quasi-physiological conditions (by the perforated patch-clamp method), the contribution made by $\mathrm{Cl}^{-}$channels to smooth muscle function may be more important than previously thought. The development of the new, selective $\mathrm{Cl}^{-}$-channel blockers as well as the identification and gene engineering of the channel molecules are essential if we are to advance our knowledge of the physiology and pharmacology of the $\mathrm{Cl}^{-}$channels residing in vascular smooth muscle cells.
\end{abstract}

Keywords: $\mathrm{Ca}^{2+}$-dependent $\mathrm{Cl}^{-}$channel, Artery, Smooth muscle, $\mathrm{Cl}^{-}$-dependent contraction, $\mathrm{Cl}^{-}$-dependent depolarization

\section{Introduction}

It is well known that L-type $\mathrm{Ca}^{2+}$ channels are important in the regulation of the intracellular $\mathrm{Ca}^{2+}$ concentration in vascular smooth muscle cells, and some other channels, such as voltage- and ligand-gated $\mathrm{K}^{+}$channels or nonselective cation channels, are known to regulate the L-type $\mathrm{Ca}^{2+}$ channels through changes in the membrane potential. In contrast, we still know comparatively little about the other type of ion channel that is abundantly distributed in the smooth muscle membrane, the $\mathrm{Cl}^{-}$channel. The $\mathrm{Cl}^{-}$conductance through the membrane of smooth muscle cells is higher than the corresponding conductances in skeletal and cardiac muscle cells. In rabbit pulmonary arterial cells, an intracellular $\mathrm{Cl}^{-}$concentration of $57 \mathrm{mM}$ has been calculated, and the relative permeability for $\mathrm{Cl}^{-}$is 0.67 against the $\mathrm{K}^{+}$permeability under resting membrane conditions (1). The calculated equilibrium potential for $\mathrm{Cl}^{-}$in these vascular cells is $-26 \mathrm{mV}(1)$, which is a high enough potential to activate the L-type $\mathrm{Ca}^{2+}$ channels in these cells, and also

*Corresponding author. FAX: +81-92-801-4909

E-mail: kenuran@college.fdcnet.ac.jp high enough to block the spontaneously generated action potential in excitable cells (depolarization block). This high $\mathrm{Cl}^{-}$conductance may be an important determinant of the indigenous membrane properties of smooth muscle cells. In actual fact, an increase in $\mathrm{Cl}^{-}$conductance produces a bidirectional response in terms of smooth muscle contraction. In vascular smooth muscle cells, which (with the exception of the portal vein) do not generate an action potential spontaneously in the presence or absence of agonists, an increase in $\mathrm{Cl}^{-}$conductance may contribute to muscle contraction. Thanks to the use of voltage-clamp methods, much evidence has accumulated to demonstrate the presence of $\mathrm{Cl}^{-}$channels in vascular smooth muscle and to elucidate their electrophysiological and pharmacological properties, but it is still not yet clear exactly how $\mathrm{Cl}^{-}$channels contribute to the regulation of smooth muscle contraction and membrane depolarization elicited by various agonists. An adequate knowledge of the current view of the properties of $\mathrm{Cl}^{-}$ channels or $\mathrm{Cl}^{-}$conductance, as they relate to the regulation of contraction, is essential for an understanding of their physiological and pathophysiological roles. The present paper reviews the present situation with regard to our 
knowledge of $\mathrm{Cl}^{-}$-channel physiology and pharmacology in vascular smooth muscle cells.

\section{Intracellular $\mathrm{Cl}^{-}$concentration}

The intracellular $\mathrm{Cl}^{-}$concentration $\left(\left[\mathrm{Cl}^{-}\right]_{\mathrm{i}}\right)$ has been measured in a number of tissues and cells using a variety of methods. Using several different methods, such as the double-barrelled microelectrode method, electron microprobe analysis and $\mathrm{Cl}^{-}$-flux measurement using a radioactive tracer, we were able to measure $\left[\mathrm{Cl}^{-}\right]_{\mathrm{i}}$ in smooth muscle tissues. However, as smooth muscle tissues have a relatively large extracellular space, the values obtained for
$\left[\mathrm{Cl}^{-}\right]_{\mathrm{i}}$ by the use of these classical methods are subject to errors. With the recent development of $\mathrm{Cl}^{-}$-sensitive fluorescent dyes (MQAE and SPQ), we are now able to measure $\left[\mathrm{Cl}^{-}\right]_{\mathrm{i}}$ in cells and tissues in which measurement was difficult in the past. However, due to the chemical properties of these dyes (high permeability through the membrane), this method, too, has limitations in terms of the precise measurement of $\left[\mathrm{Cl}^{-}\right]_{\mathrm{i}}$ in tissue preparations.

In smooth muscle cells, $\left[\mathrm{Cl}^{-}\right]_{\mathrm{i}}$ is reported to be ca. $50 \mathrm{mM}$, as measured by tracer and ion-selective electrode methods $(1-4)$. These values are somewhat larger than that measured in cardiac cells $(5-8)$ (Table 1) and that

Table 1. Intracellular $\mathrm{Cl}^{-}$concentrations in various cells

\begin{tabular}{|c|c|c|c|c|c|}
\hline Tissue & Cell & Species & $\begin{array}{l}\text { Intracellular } \mathrm{Cl}^{-} \\
\text {concentration }(\mathrm{mM})\end{array}$ & Tools & References \\
\hline \multirow[t]{5}{*}{ Smooth muscle tissue } & pulmonary artery & rabbit & 51 & radioisotope & 1 \\
\hline & aorta & rat & $31.6 \pm 3.2$ & fluorescent dye (MQAE) & 8 \\
\hline & vas deferens & guinea pig & 53.9 & radioisotope & 2 \\
\hline & taenia caeci & guinea pig & $49-56$ & radioisotope & 3 \\
\hline & ureter & guinea pig & 51.1 & ion-selective electrode & 4 \\
\hline \multirow[t]{5}{*}{ Cardiac tissue } & ventricular cell & rat & $21.3 \pm 1.5$ & ion-selective electrode & 5 \\
\hline & ventricular cell & guinea pig & $18.7 \pm 3.5$ & ion-selective electrode & 6 \\
\hline & heart & chick & $25.1 \pm 7.3$ & radioisotope & 7 \\
\hline & papillary muscle & rabbit & $15.2 \pm 0.6$ (bicarbonate) & radioisotope & 8 \\
\hline & & & $24.1 \pm 0.6(\mathrm{HEPES})$ & & \\
\hline \multirow[t]{5}{*}{ Epithelial tissue } & aortic endothelial cell & human & 34 & patch clamp & a) \\
\hline & tracheal epithelial cell & $\operatorname{dog}$ & $43 \pm 4$ & fluorescent dye (SPQ) & b) \\
\hline & corneal epithelium & rabbit & 30,41 & microelectrode & c), d) \\
\hline & renal epithelial cell & rat & 28 & electron probe analysis & e) \\
\hline & proximal tubule & rabbit & $17.8 \pm 0.5$ & ion-selective electrode & f) \\
\hline \multirow[t]{13}{*}{ Neurons \& others } & olfactory cell & newt & 40 & fluorescent dye (MQAE) & g) \\
\hline & brain synaptosome & rat & $14 \pm 4$ & fluorescent dye (MQAE) & h) \\
\hline & Dieter's neuron & rabbit & 21 & radioisotope & i) \\
\hline & cochlear hair cell & guinea pig & $8.3 \pm 0.9$ & fluorescent dye (MQAE) & j) \\
\hline & epididymal cell & rat & $62.3 \pm 0.2$ & fluorescent dye (SPQ) & k) \\
\hline & $\begin{array}{l}\text { kidney cortical thick } \\
\text { ascending limb }\end{array}$ & rabbit & $58.8 \pm 7.2$ & fluorescent dye (SPQ) & 1) \\
\hline & kidney macula densa & rabbit & $68.7 \pm 9.8$ & fluorescent dye (SPQ) & 1) \\
\hline & gallbladder & Nect-urus & $12 \pm 2$ & ion-selective electrode & m) \\
\hline & red blood cell & lamprey & $57.6 \pm 5.2$ & ion-selective electrode & n) \\
\hline & lymphocyte & rat & $70-85$ & radioisotope & o) \\
\hline & parotid acinar cell & rat & 62.3 & radioisotope & p) \\
\hline & fibroblast & human & $53.4 \pm 3.4$ & fluorescent dye (MQAE) & q) \\
\hline & rectotroph cell & rat & 59.4 & fluorescent dye (SPQ) & r) \\
\hline
\end{tabular}

a) Ono et al.: J Physiol 511, 837 - 849 (1998); b) Chao et al.: J Memb Biol 113, 193 - 202 (1990); c) Klyce \& Wong: J Physiol (Lond) 266, 777 - 799 (1977); d) Yasukura et al.: Jpn J Pharmacol 67, 315 - 320 (1995); e) Larsson et al.: Acta Physiol Scand 126, 321 - 332 (1986); f) Ishibashi et al.: Am J Physiol 255, F49 - F56 (1988); g) Nakamura et al.: Neurosci Lett 237, 5 -8 (1997); h) Engblom \& Åkerman: Biochim Biophys Acta 1153, 262 - 266 (1993); i) Rapallino et al.: Int J Neurosci 53, 135 - 141 (1990); j) Ohnishi et al.: Am J Physiol 263, C1088 - C1095 (1992); k) Huang et al.: J Physiol (Lond) 474, 183 - 194 (1994); 1$)$ Salomomsson et al.: Acta Physiol Scand 147, $305-313$ (1993); m) Fernando-Garcia-Diaz et al.: J Membr Biol 73, 145 - 155 (1983); n) Bogdanova et al.: J Exp Biol 201, 693 - 700 (1998); o) Garcia-Soto \& Grinstein: Am J Physiol 258, C1108 - C1116 (1990); p) Nauntofte \& Dissing: Proc Finn Dent Soc 85, 307 - 317 (1989); q) Maglova et al.: Am J Physiol 275, C1330 - C1341 (1998); r) Garcia et al.: FEBS Lett 400, 113 - 118 (1997). 
measured in cultured rat aorta cells using a $\mathrm{Cl}^{-}$-sensitive fluorescent dye (MQAE) (31.6 mM) (9). The calculated reversal potentials for $\mathrm{Cl}^{-}$were -29 and $-40 \mathrm{mV}$, respectively, in these two preparations. These values of the reversal potential are marginal in terms of ability to activate voltage-dependent $\mathrm{Ca}^{2+}$ channels; however, a comparison of the contractions and depolarizations (achieved by increase in the extracellular $\mathrm{K}^{+}$concentration) shows that a depolarization to $-40 \mathrm{mV}$ is sufficient to produce contraction in smooth muscle cells (1). Extracellular $\mathrm{Ca}^{2+}$ is thought to be the main source of $\mathrm{Ca}^{2+}$ for smooth muscle contraction, especially for the tonic component, and activation of $\mathrm{Cl}^{-}$channels and changes in $\left[\mathrm{Cl}^{-}\right]_{\mathrm{i}}$ are important because they regulate the activity of L-type $\mathrm{Ca}^{2+}$ channels.

\section{$\mathrm{Cl}^{-}$currents recorded in vascular cells}

Two major $\mathrm{Cl}^{-}$currents have been described in vascular smooth muscle cells, namely, $\mathrm{Ca}^{2+}$-dependent $\mathrm{Cl}^{-}$and volume-regulated $\mathrm{Cl}^{-}$currents. The channel molecules responsible for the latter $\mathrm{Cl}^{-}$current may be the $\mathrm{ClC}-3$ isoform (ref. 10; also see review, ref. 11). The volume-regulated $\mathrm{Cl}^{-}$channel can be activated experimentally by low osmotic pressure (perfusion with a hypotonic solution) or by certain pathological conditions. This $\mathrm{Cl}^{-}$channel has also been reported to be activated by mechanical stress, which occurs during vascular distension caused by a rise in systolic pressure, and by urinary retention in the bladder etc. In these cases, a shift in the cellular responses toward contraction clearly favors both the maintenance of tissue integnity and systemic stability against mechanical stretch. Nelson et al. (12) demonstrated that raising the pressure in the cerebral artery to $80 \mathrm{mmHg}$ depolarized the membrane, while $\mathrm{Cl}^{-}$channel blockers, IAA-94 (indaryloxyacetic acid) and DIDS (4,4'-diisothiocyanatostilbene-2,2'-disulphonic acid), hyperpolarized the membrane and relaxed the tissue. These results indicated that stretching the vessel wall by increasing blood pressure activated the volume-regulated $\mathrm{Cl}^{-}$ channels and reduced the arterial diameter. The same group recently showed that the above $\mathrm{Cl}^{-}$-channel blockers also suppressed the non-selective cationic current (13). Thus, the importance of $\mathrm{Cl}^{-}$channels to the pressure-induced response should promote further study and discussion, and development of selective $\mathrm{Cl}^{-}$-channel blockers would be an important aid to such investigations.

By use of the patch-clamp technique, $\mathrm{Ca}^{2+}$-dependent $\mathrm{Cl}^{-}$ currents have been identified in various smooth muscle tissues, including vascular ones. It is of interest that it was the perforated patch-clamp technique (involving the use of nystatin or other antibiotics), rather than the conventional whole-cell voltage-clamp technique, that revealed the $\mathrm{Ca}^{2+}$ dependent $\mathrm{Cl}^{-}$current following agonist stimulation (14). This may reflect differences in the $\mathrm{Ca}^{2+}$-buffering system between the two techniques. In case of the conventional whole-cell voltage-clamp technique, a strong $\mathrm{Ca}^{2+}$ chelater was always present in the pipette solution to maintain a low $\mathrm{Ca}^{2+}$ concentration within the cell $\left(\left[\mathrm{Ca}^{2+}\right]_{i}\right)$, whereas $\left[\mathrm{Ca}^{2+}\right]_{\mathrm{i}}$ is regulated by its own biological system in the perforated patch-clamp tehnique. Thus, the perforated patchclamp technique keeps conditions more physiological, and quasi-physiological responses may therefore be seen in the cells under study. There are various pieces of evidence to suggest that the agonist-induced inward current is $\mathrm{Ca}^{2+}$-dependent: i) low concentration of niflumic acid and stilbene derivatives partly inhibited the norepinephrine-induced inward current in the rabbit portal vein (15), while high concentrations completely blocked the histamine-induced inward current in the rabbit basilar artery (16); ii) removal of extracellular $\mathrm{Ca}^{2+}$ ultimately inhibited the agonist-induced inward current; and iii) the reversal potential of the agonist-induced inward current depended upon $\left[\mathrm{Cl}^{-}\right]_{\mathrm{i}}$ and $\left[\mathrm{Cl}^{-}\right]_{\mathrm{o}}$, but not on $\left[\mathrm{Na}^{+}\right]_{\mathrm{o}}$ and $\left[\mathrm{K}^{+}\right]_{\mathrm{o}}$ concentration. Furthermore, a redution in the amplitude of the agonist-induced current occurred following pretreatment with caffeine, CPA (cyclopiazonic acid) or thapsigargin. Thus, $\mathrm{Ca}^{2+}$ release from the caffeine-sensitive intracellular $\mathrm{Ca}^{2+}$ store sites and $\mathrm{Ca}^{2+}$ influx through L-type $\mathrm{Ca}^{2+}$ channels would seem to be important for activation of the $\mathrm{Ca}^{2+}$-dependent $\mathrm{Cl}^{-}$channels in these preparations. The $\mathrm{Ca}^{2+}$-dependent $\mathrm{Cl}^{-}$current is mainly activated by receptor stimulation in vascular cells; however, in some cases, $\mathrm{Cl}^{-}$currents have been reported to be spontaneously activated. As spontaneous $\mathrm{Cl}^{-}$currents were synchronously generated by the spontaneously $\mathrm{Ca}^{2+}$ dependent $\mathrm{K}^{+}$currents $(17,18)$, this $\mathrm{Cl}^{-}$current was thought to be activated by $\mathrm{Ca}^{2+}$ release from the store sites.

The anion permeability of $\mathrm{Ca}^{2+}$-dependent $\mathrm{Cl}^{-}$channels has been widely tested (see review, ref. 17). The order of anion permeability for $\mathrm{Ca}^{2+}$-dependent $\mathrm{Cl}^{-}$channels is $\mathrm{SCN}^{-}>\mathrm{I}^{-}>\mathrm{NO}_{3}^{-}>\mathrm{Br}^{-}>\mathrm{Cl}^{-}>$glutamate, which is a similar to the reported order for the volume-regulated $\mathrm{Cl}^{-}$ current in vascular cells and for the $\mathrm{ClC}-3$ channel $\left(\mathrm{I}^{-}>\mathrm{Br}^{-}\right.$ $\left.>\mathrm{Cl}^{-}\right)(11,19)$. This order of anion permeability differs from those reported for other types of $\mathrm{Cl}^{-}$channels such as ClC-0, $\mathrm{ClC}-1, \mathrm{ClC}-2$ and $\mathrm{ClC}-5$ channels. The two types of $\mathrm{Cl}^{-}$current $\left(\mathrm{Ca}^{2+}\right.$-dependent and volume-regulated $\mathrm{Cl}^{-}$ channels) can be separated by the use of certain channel blockers. Niflumic acid is one such blocker, and this agent inhibits $\mathrm{Ca}^{2+}$-dependent $\mathrm{Cl}^{-}$channels, but not volume-regulated $\mathrm{Cl}^{-}$channels. DIDS, a stilbene derivative, is also known to inhibit the $\mathrm{Ca}^{2+}$-dependent $\mathrm{Cl}^{-}$channel rather than the volume-regulated channel.

\section{Contribution of $\mathrm{Cl}^{-}$conductance to smooth muscle con- traction}

To assess the physiological role played by $\mathrm{Cl}^{-}$conductance in vascular smooth muscle cells, Criddle et al. (20, 21 ) examined the effects of niflumic acid on both $\mathrm{K}^{+}$- and 
agonist-induced contractions. They showed that niflumic acid $(1-30 \mu \mathrm{M})$ selectively inhibited the agonist-induced contraction without changing the high $\mathrm{K}^{+}$-induced contraction in both the rat aorta and rat mesenteric artery. Niflumic acid $(30 \mu \mathrm{M})$, but not mefenamic acid $(100 \mu \mathrm{M})$, was later shown by our group to reduce the amplitude of the histamine-induced contraction in the rabbit basilar artery without inhibiting the high $\mathrm{K}^{+}$-induced contraction (22). This niflumic acid-induced inhibition was predominantly observed in the early phase of the agonist-induced contraction. Although a high concentration of niflumic acid blocks the high $\mathrm{K}^{+}$-induced contraction, the contribution made by the $\mathrm{Ca}^{2+}$-dependent $\mathrm{Cl}^{-}$conductance to the contraction could be measured by carefully choosing the concentration of niflumic acid used. Criddle et al. (20) thought that the inhibitory action of niflumic acid on the agonist-induced contraction targeted $\mathrm{Ca}^{2+}$ influx through L-type $\mathrm{Ca}^{2+}$ channels since niflumic acid reduced neither the amplitude of the phasic contraction observed in $\mathrm{Ca}^{2+}$-free solution (17) nor the $\mathrm{Ca}^{2+}$-dependent $\mathrm{K}^{+}$current. On the other hand, Hogg et al. (15) thought that niflumic acid might act on the $\mathrm{Ca}^{2+}$ release mechanism on the basis of their observations. In our study (ref. 23, rabbit basilar artery), since a long exposure to niflumic acid ( $1 \mathrm{~h}$ or longer) led to the amplitude of the phasic contraction being reduced, a niflumic-acid-sensitive mechanism might contribute to an initial increase in the intracellular $\mathrm{Ca}^{2+}$ concentration through $\mathrm{Ca}^{2+}$ release from the intracellular $\mathrm{Ca}^{2+}$ store sites and resulted in contraction.

There have been several reports of the effects on smooth muscle contraction resulting from the replacement of extracellular $\mathrm{Cl}^{-}$ions by other permeable or impermeable anions. Saha et al. (24) showed that use of $\mathrm{Cl}^{-}$-deficient solution $\left(\mathrm{Cl}^{-}\right.$substituted by glucronate and gluconate) reduced the muscle tone of the lower esophageal sphincter muscle of the opposum without changing the acetylcholine-induced contraction. This relaxation could be mimicked by application of the $\mathrm{Cl}^{-}$-channel blockers, NPPB (5-nitro-2-(3phenylpropylamino)benzoic acid) and IAA-94, suggesting an important contribution of $\mathrm{Cl}^{-}$conductance to esophageal muscle tone in the opposum. In rabbit basilar artery, use of low $\mathrm{Cl}^{-}$solution $\left(\mathrm{Cl}^{-}\right.$substituted by several impermeable anions) reduced the amplitude of the histamine-induced contraction without changing the high $\mathrm{K}^{+}$-induced contraction (23). In this preparation, histamine is a strong constrictor through activation of the $\mathrm{H}_{1}$-receptor (16), and it induces a phasic contraction followed by a tonic contraction. The former depends on $\mathrm{Ca}^{2+}$ release from the store sites and the latter, on $\mathrm{Ca}^{2+}$ influx through L-type $\mathrm{Ca}^{2+}$ channels (Fig. 1). The typical effects produced by the use of low $\mathrm{Cl}^{-}$ solution on the histamine-induced contraction in the rabbit basilar artery are i) suppression of the phasic contraction, ii) suppression of the rate of rise of the tonic contraction and iii) increase in the rate of relaxation (Fig. 1). Thus, $\mathrm{Cl}^{-}$ conductance contributes to the enhancement of both the $\mathrm{Ca}^{2+}$-induced $\mathrm{Ca}^{2+}$ release mechanism and $\mathrm{Ca}^{2+}$ influx. The rank order of potencies for the inhibitory effects of impermeable anions on the contraction resembled the rank order of permeabilities for the $\mathrm{Ca}^{2+}$-dependent $\mathrm{Cl}^{-}$channels in rat lacrimal gland cells (25).

Any direct evidence in favor of a contribution by $\mathrm{Cl}^{-}$ conductance in the plasmalemma to $\mathrm{Ca}^{2+}$ release from the sarcoplasmic reticulum (SR) is scarce, but few papers showed mutual relationships between $\mathrm{Cl}^{-}$conductance on the SR membrane and the $\mathrm{Ca}^{2+}$ release from the ryanodine receptors. Using organic anions, Fruen et al. (26) demonstrated that substitution of $\mathrm{Cl}^{-}$by propionate reduced $\mathrm{Ca}^{2+}$ release via a reduction in the functional rynodine receptor in skeletal muscle SR, but not in cardiac muscle SR. Thus, it is not clear whether and how $\mathrm{Cl}^{-}$conductance on the $\mathrm{SR}$ mambrane participates in $\mathrm{Ca}^{2+}$ release from the SR. The difference observed between skeletal and cardiac muscles may due to the known presence of different ryanodine recepters in the two muscles, skeletal muscle possessing RYR-1 and RYR-3 receptors, whereas cardiac muscle possesses the RYR-2 receptor. All three types of RYR receptors may contribute to the $\mathrm{Ca}^{2+}$-induced $\mathrm{Ca}^{2+}$ release

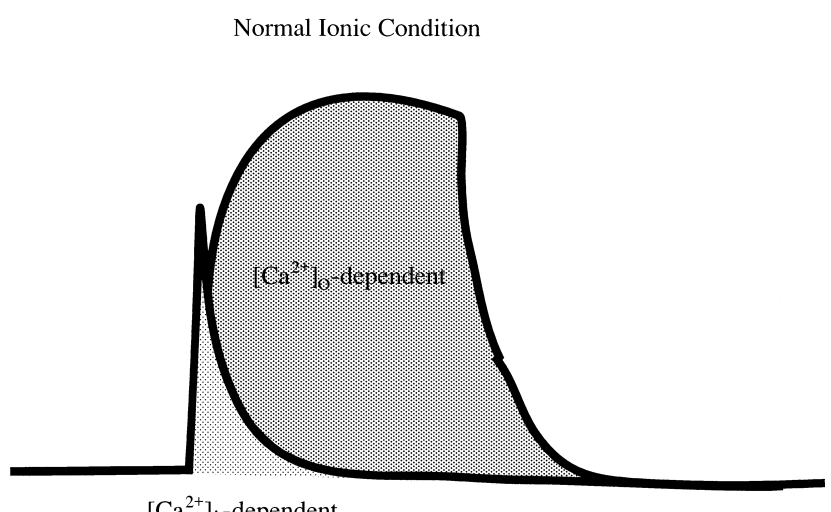

$\left[\mathrm{Ca}^{2+}\right]_{\mathrm{i}}$-dependent

Low $\mathrm{Cl}^{-}$Condition

Reduced amplitude of phasic contraction

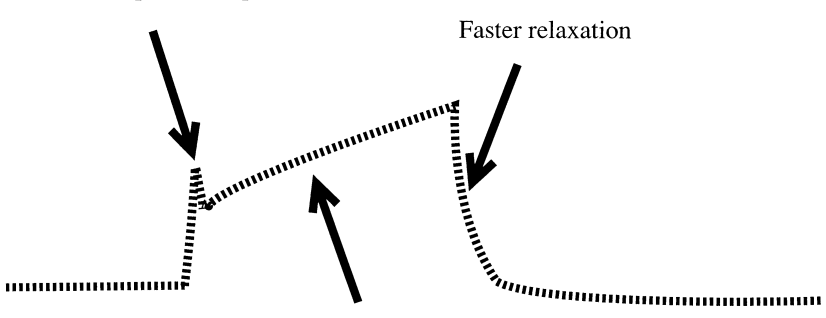

Slower development of tonic contraction

Fig. 1. Agonist-induced arterial contraction and its $\left[\mathrm{Cl}^{-}\right]_{0}$-dependency. 
mechanism in these cells, although it was reliably reported that $\mathrm{Cl}^{-}$-dependent activation of $\mathrm{Ca}^{2+}$ release occurs through the RYR-1 receptor in skeletal muscle (27). In the case of smooth muscle cells, it has been reported that RYR-2 and RYR-3 receptor genes are both present. If we assume that the RYR-2 receptor does not mediate $\mathrm{Cl}^{-}$-dependent $\mathrm{Ca}^{2+}$ release in smooth muscle cells, as it is reported to do in cardiac RYR-2 (27), then the RYR-3 receptor may mediate $\mathrm{Ca}^{2+}$ release from the $\mathrm{SR}$ in smooth muscle cells. As replacement of $\mathrm{Cl}^{-}$with methanesulfonate reduced the $\mathrm{Ca}^{2+}$ induced $\mathrm{Ca}^{2+}$ release in the skeletal muscle of RYR-1 knock-out mice (27), both RYR-1 and RYR-3 receptors seem to be regulated by the intracellular $\mathrm{Cl}^{-}$concentration in skeletal muscle. Pollock et al. (14) reported no inhibition of $\mathrm{Ca}^{2+}$ uptake by niflumic acid in a rabbit stomach smooth muscle preparation, although several other $\mathrm{Cl}^{-}$-channel blockers did have an inhibitory action.

When $\left[\mathrm{Cl}^{-}\right]_{\mathrm{o}}$ was reduced to $60 \mathrm{mM}\left(\mathrm{Cl}^{-}\right.$substituted by glutamate), an increase in pressure in the lumen augmented the myogenic tone in the cerebral artery (28). The authors concluded that this might be caused by an increase in $\left[\mathrm{Ca}^{2+}\right]_{\mathrm{i}}$ through activation of the L-type $\mathrm{Ca}^{2+}$ channels, as the membrane was depolarized by a reduction in $\left[\mathrm{Cl}^{-}\right]_{\mathrm{o}}$ through a positive shift in the $\mathrm{Cl}^{-}$reversal potential. Indeed, in the aorta when $\mathrm{Cl}^{-}$was replaced by the permeable anion, $\mathrm{SCN}$, there was a transient decrease in $\left[\mathrm{Ca}^{2+}\right]_{\mathrm{i}}$ followed the hyperpolarization of the membrane, and then $\left[\mathrm{Ca}^{2+}\right]_{\mathrm{i}}$ gradually increased within $20 \mathrm{~min}$ (28). When pressure was raised within the mesenteric artery, norepinephrine and 5-hydroxytryptamine both induced a contraction closely related to the $\mathrm{Ca}^{2+}$-dependent $\mathrm{Cl}^{-}$current without a change in the resting myogenic tone, whereas in cerebral artery stretched by strong pressure, a volume-regulated $\mathrm{Cl}^{-}$current was activated under resting conditions $(12,21)$. As the former contraction was inhibited by niflumic acid, but not the latter, different $\mathrm{Cl}^{-}$currents would appear to have been activated by the above maneuvers.

\section{Contribution of $\mathrm{Cl}^{-}$conductance to the membrane potential}

Although much electrophysiological evidence of the presence of $\mathrm{a} \mathrm{Cl}^{-}$current and of its contribution to agonistinduced responses has been obtained in patch-clamp experiments, very few papers have been published in which microelectrode methods have been used. In anococcygeous muscle cells, Byrne and Large (29) reported that norepinephrine produced a membrane depolarization, the initial component of which was sensitive to $\left[\mathrm{Cl}^{-}\right]_{\mathrm{o}}$ (as substitution of $\mathrm{Cl}^{-}$by the impermeable anion benzensulfonate abolished the initial membrane depolarization induced by norepinephrine). In these cells, although low $\mathrm{Cl}^{-}$conditions inhibited the initial phase of the norepinephrine-induced contraction, its maximum amplitude remained unaltered, a result in good agreement with the effect of such conditions on the membrane potential (30). Recently, Gokina and Bevan (31) showed that niflumic acid, as well as DIDS, inhibited the membrane depolarization induced by histamine in the rabbit middle cerebral artery. Although a short application of niflumic acid did not produce a distinct repolarization on the histamine-induced depolarization in the rabbit basilar artery, a long pretreatment with niflumic acid could inhibit the depolarization (23). Similarly, superfusion with low- $\mathrm{Cl}^{-}$solution $\left(\mathrm{Cl}^{-}\right.$substituted by impermeable anions) inhibited the histamine-induced depolarization (23). All these results indicate that part of the depolarization evoked by agonists was mediated by an activation of $\mathrm{Ca}^{2+}$-dependent $\mathrm{Cl}^{-}$conductance.

\section{Summary}

Taken together, the above reports demonstrate a contribution of $\mathrm{Cl}^{-}$channels to agonist-induced contractions in vascular and other smooth muscle cells (Table 2). As blocker of $\mathrm{Ca}^{2+}$-dependent $\mathrm{Cl}^{-}$channels inhibited the early depolarization in the anococcygeous muscle, it would seem that the contraction that follows $\mathrm{Ca}^{2+}$ release by agonists is

Table 2. Roles of $\mathrm{Cl}^{-}$channels in smooth muscle cells

\begin{tabular}{|c|c|c|c|c|}
\hline Type & Gene & Supposed roles of $\mathrm{Cl}^{-}$channels & Blockers or conditions (their actions) & References \\
\hline \multirow[t]{6}{*}{$\mathrm{Ca}^{2+}$-dependent $\mathrm{Cl}^{-}$channels } & $?$ & contraction (early phase) & niflumic acid (relaxation) & $20,21,22$ \\
\hline & & tonic contraction & gluconate substitution (relaxation) & 24 \\
\hline & & & NPPB \& IAA-94 (relaxation) & 24 \\
\hline & & contraction (early phase) & impearmeable anions (relaxation) & 23,30 \\
\hline & & depolarization & impearmeable anions (repolarization) & 29 \\
\hline & & depolarization & niflumic acid \& DIDS (repolarization) & 23,31 \\
\hline \multirow[t]{2}{*}{ Volume-regulated $\mathrm{Cl}^{-}$channels } & $\mathrm{ClC}-3$ & osmotic homeostasis & $\begin{array}{l}\text { IAA-94 \& DIDS } \\
\text { (hyperpolarization \& relaxation) }\end{array}$ & 12 \\
\hline & & & $\begin{array}{l}\text { niflumic acid (no effect on membrane } \\
\text { potential and contraction) }\end{array}$ & 12 \\
\hline $\mathrm{Cl}^{-}$channels in SR membrane & & osmotic homeostasis & niflumic acid (no effect on $\mathrm{Ca}^{2+}$ uptake) & 14 \\
\hline
\end{tabular}




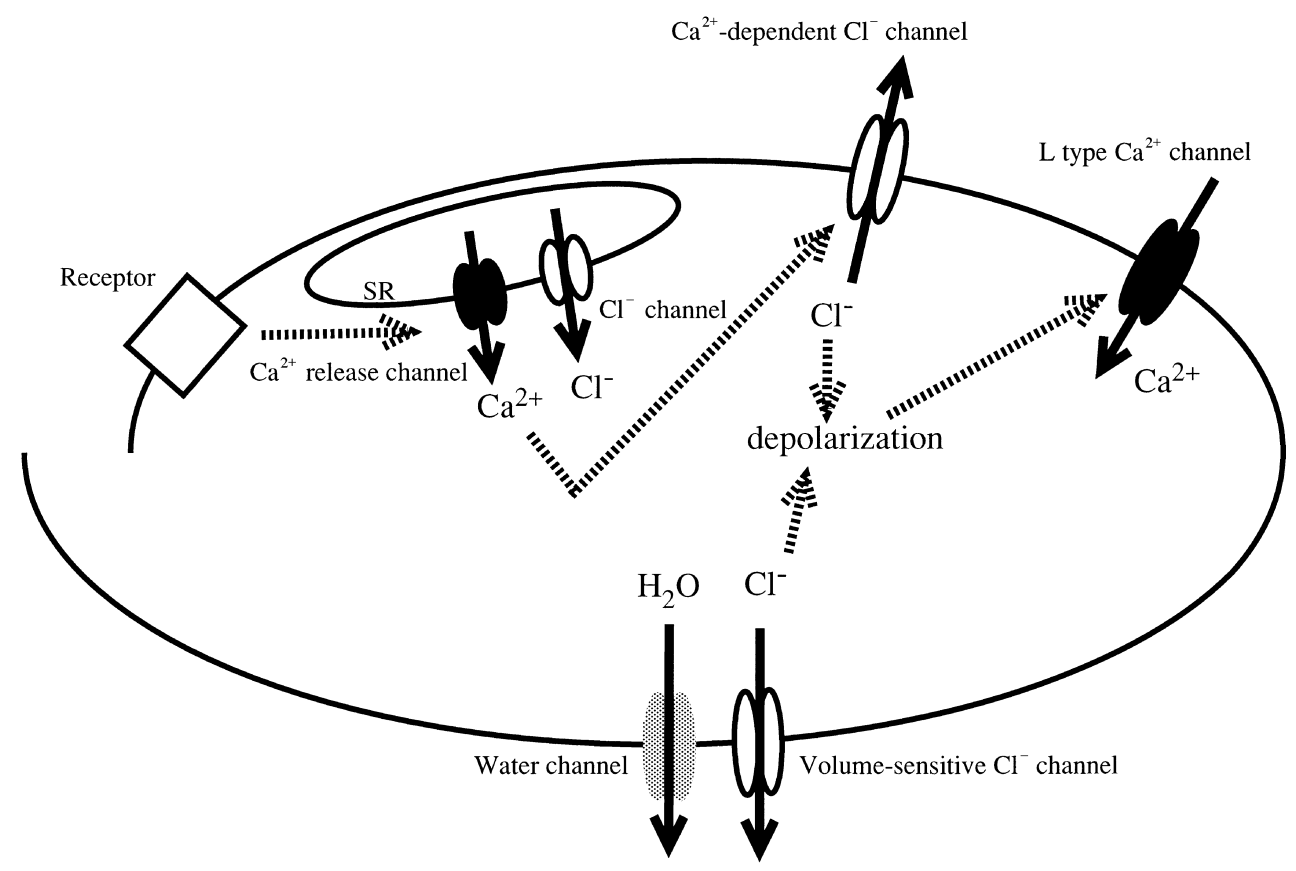

Fig. 2. Role of $\mathrm{Cl}^{-}$channels in vascular smooth muscle cell.

directly regulated by $\mathrm{Cl}^{-}$membrane conductance. Results from patch-clamp experiments have shown that niflumic acid $(<50 \mu \mathrm{M})$ does not modify $\mathrm{Ca}^{2+}$ release by agonists and caffeine, as the $\mathrm{Ca}^{2+}$-dependent $\mathrm{K}^{+}$current was not inhibited by their blocker (32). There is good evidence that the agonist-induced inward current can be attributed to $\mathrm{Ca}^{2+}$ release from the SR (pretreatment with caffeine or superfusion with $\mathrm{Ca}^{2+}$-free solution inhibited the agonist-induced $\mathrm{Cl}^{-}$current), and that an increase in $\left[\mathrm{Ca}^{2+}\right]_{\mathrm{i}}$ via the $\mathrm{SR}$ is essential for activation of $\mathrm{Ca}^{2+}$-dependent $\mathrm{Cl}^{-}$channels. On the other hand, a block of L-type $\mathrm{Ca}^{2+}$ channels by $\mathrm{Ca}^{2+}$ antagonists did not greatly change the agonist-induced depolarization of the membrane. Thus, a conclusion that $\mathrm{Cl}^{-}$dependent membrane depolarization may regulate L-type $\mathrm{Ca}^{2+}$-channel activation seems to be appropriate (Fig. 2). It is uncertain why $\mathrm{Ca}^{2+}$-dependent $\mathrm{Cl}^{-}$channels are opened by an increase in $\left[\mathrm{Ca}^{2+}\right]_{\mathrm{i}}$ caused by $\mathrm{Ca}^{2+}$ release from the store sites, but not by an increase in $\left[\mathrm{Ca}^{2+}\right]_{\mathrm{i}}$ caused directly by $\mathrm{Ca}^{2+}$ influx through L-type $\mathrm{Ca}^{2+}$ channels. In hair cells, Issa and Hudspeth (33) demonstrated a clustering and colocalization of $\mathrm{Ca}^{2+}$ channels and $\mathrm{Ca}^{2+}$-dependent $\mathrm{K}^{+}$channels in the presynaptic active zone. Although no evidence that clustering also occurs in smooth muscle has so far been published, it could be that $\mathrm{Ca}^{2+}$-dependent $\mathrm{Cl}^{-}$channels are more densely distributed close to the $\mathrm{Ca}^{2+}$ store sites, so that activation of these channels can easily occur following a $\left[\mathrm{Ca}^{2+}\right]_{\mathrm{i}}$ increase through $\mathrm{Ca}^{2+}$ release. One other possible reason, for there being distinct contributions by store sites and L-type $\mathrm{Ca}^{2+}$ channels to the activation of $\mathrm{Ca}^{2+}$-depend- ent $\mathrm{Cl}^{-}$channels, include the predominant contribution to tonic contraction being made by agonist-induced nonselective cation channels.

To assess the physiological and pathophysiological roles played by $\mathrm{Cl}^{-}$channels, a more specific channel blocker is required, as the present channel blockers, such as niflumic acid and stilbene derivatives, are known to act at various sites. Furthermore, replacement of $\mathrm{Cl}^{-}$by other organic and inorganic anions changes the cellular conditions such as intracellular $\mathrm{pH}$ and cell volume through a suppression of $\mathrm{Cl}^{-}$-sensitive exchangers and other $\mathrm{Cl}^{-}$channels. Indeed, experiments with low $\mathrm{Cl}^{-}$solution have produced a wide variety of effects in anococcygeous and vascular smooth muscle cells $(23,29)$. The results of such experiments might depend upon whether the substitutes do or do not have an action similar to that of $\mathrm{Cl}^{-}$, which will be strongly related to their permeability through the cell and SR membranes.

\section{REFERENCES}

1 Casteels R, Kitamura K, Kuriyama $\mathrm{H}$ and Suzuki H: The membrane properties of the smooth muscle cells of the rabbit main pulmonary artery. J Physiol (Lond) 271, 41 - 61 (1977)

2 Aickin $\mathrm{CC}$ and Brading AF: Measurement of intracellular chloride in guinea-pig vas deferens by ion analysis, ${ }^{36} \mathrm{Cl}$ efflux and microelectrodes. J Physiol (Lond) 326, 139 - 154 (1982)

3 Brading AF: Analysis of the effluxes of sodium, potassium and chloride ions from smooth muscle in normal and hypertonic solutions. J Physiol (Lond) 214, 393 - 416 (1971) 
4 Aickin CC and Vermue NA: Microelectrode measurement of intracellular chloride activity in smooth muscle cells of guineapig ureter. Pflugers Arch 397, 25 - 28 (1983)

5 Chipperfield AR, Davis JP and Harper AA: Sodium-independent inward chloride pumping in rat cardiac ventricular cells. Am J Physiol 272, H735 - H739 (1997)

6 Lai ZF and Nishi K: Intracellular chloride activity increases in guinea-pig ventricular muscle during stimulated ischemia. Am J Physiol 275, H1613 - H1619 (1998)

7 Piwnica-Worms D, Jacob R, Horres CR and Lieberman N: Transmembrane chloride flux in tissue-cultured chick heart cells. J Gen Physiol 81, 731 - 748 (1983)

8 Fong $\mathrm{CN}$ and Hinke JA: Intracellular $\mathrm{Cl}$ activity, $\mathrm{Cl}$ binding, and ${ }^{36} \mathrm{Cl}$ efflux in rabbit papillary muscle. Can J Physiol Pharmacol 59, 479 - 484 (1981)

9 Koncz C and Daugirdas JT: Use of MQAE for measurement of intracellular $\left[\mathrm{Cl}^{-}\right]$in cultured aortic smooth muscle cells. Am J Physiol 267, H2114 - H2123 (1994)

10 Yamazaki J, Duan D, Janiak R, Kuenzli K, Horowitz B and Hume JR: Functional and molecular expression of volume-regulated chloride channels in canine vascular smooth muscle cells. J Physiol (Lond) 507, 729 - 736 (1998)

11 Yamazaki $\mathrm{J}$ and Kitamura K: Ion channels in vascular smooth muscle. In Heart Physiology and Pathophysiology, 4th Ed, Edited by Sperelakis N, Kurachi Y, Terzic A and Cohen MV, pp 327 - 355, Academic Press, San Diego (2000)

12 Nelson MT, Conway MA, Knot HJ and Brayden JE: Chloride channel blockers inhibit myogenic tone in rat cerebral arteries. J Physiol (Lond) 502, 259 - 264 (1997)

13 Welsh DG, Nelson MT, Eckman DM and Brayden JE: Swellingactivated cation channels mediate depolarization of rat cerebrovascular smooth muscle by hyposmolarity and intravascular pressure. J Physiol (Lond) 527, 139 - 148 (2000)

14 Pollock NS, Kargacin ME and Kargacin GJ: Chloride channel blockers inhibit $\mathrm{Ca}^{2+}$ uptake by the smooth muscle sarcoplasmic reticulum. Biophys J 75, 1759 - 1766 (1998)

15 Hogg RC, Wang Q and Large WA: Action of niflumic acid on evoked and spontaneous calcium-activated chloride and potassium currents in smooth muscle cells from rabbit portal vein. Br J Pharmacol 112, 977 - 984 (1994)

16 Kamouchi M, Ogata R, Fujishima M, Ito Y and Kitamura K: Membrane currents evoked by histamine in rabbit basilar artery. Am J Physiol 272, H638 - H647 (1997)

17 Large WA and Wang Q: Characteristics and physiological role of the $\mathrm{Ca}^{2+}$-activated $\mathrm{Cl}^{-}$cnductance in smooth muscle. Am J Physiol 271, C435 - C454 (1996)

18 Kamouchi M, Fujishima M, Ito $\mathrm{Y}$ and Kitamura K: Simultaneous activation of $\mathrm{Ca}^{2+}$-dependent $\mathrm{K}^{+}$and $\mathrm{Cl}^{-}$currents by various forms of stimulation in the membrane of smooth muscle cells from the rabbit bailar artery. J Smooth Muscle Res 34, 57 68 (1998)

19 Greenwood IA and Large WA: Properties of a $\mathrm{Cl}^{-}$current activated by cell swelling in rabbit portal vein vascular smooth muscle cells. Am J Physiol 275, H1524 - H1532 (1998)

20 Criddle DN, Soares de Moura R, Greenwood IA and Large WA: Effects of niflumic acid on noradrenaline-induced contractions of the rat aorta. Br J Pharmacol 118, 1065 - 1071 (1996)

21 Criddle DN, Soares de Moura R, Greenwood IA and Large WA: Inhibitory action of niflumic acid on noradrenaline- and 5hydroxytryptamine-induced pressor responses in the isolated mesenteric vascular bed of the rat. Br J Pharmacol 120, $813-$ $818(1996)$

22 Uchida R, Nishijima H, Yamazaki J, Shimamura K and Kitamura $\mathrm{K}$ : Effects of $\mathrm{Cl}$ channel blockers on the contractions recorded in rabbit basilar artery. Jpn J Pharmacol 79, Suppl I, 210P (1990)

23 Uchida R, Nishijima H, Yamazaki J, Shimamura K, Kato K, Ohkubo $\mathrm{T}$ and Kitamura $\mathrm{K}$ : Inhibition of histamine-induced contraction during a long exposure to low $[\mathrm{Cl}]_{\mathrm{o}}$ condition of the rabbit basilar artery. Jpn J Pharmacol 82, Suppl I, 208P (2000)

24 Saha JK, Sengupta JN and Goyal RK: Role of chloride ions in lower esophageal sphincter tone and relaxation. Am J Physiol 263, G115 - G126 (1992)

25 Evans MG and Marty A: Calcium-dependent chloride currents in isolated cells from rat lacrimal glands. J Physiol (Lond) 378, $437-460$ (1986)

26 Fruen BR, Kane PK, Mickelson JR and Louis CF: Chloridedependent sarcoplasmic reticulum $\mathrm{Ca}^{2+}$ release correlates with increased $\mathrm{Ca}^{2+}$ activation of ryanodine receptors. Biophys $\mathrm{J}$ 71, $2522-2530$ (1996)

27 Ikemoto T, Komazaki S, Takeshima H, Nishi M, Noda T, Iino $\mathrm{M}$ and Endo $\mathrm{M}$ : Functional and morphorogical features of skeletal muscle from mutant mice lacking both type 1 and type 3 ryanodine receptors. J Physiol (Lond) 501, 305 - 312 (1997)

28 Standley PR, Zhang F, Ravi J, Ram JL and Sowers JR: Effects of SCN substitution for $\mathrm{Cl}^{-}$on tension, $\left[\mathrm{Ca}^{2+}\right]$, and ionic currents in vascular smooth muscle. Life Sci 59, 739 - 752 (1996)

29 Byrne NG and Large WA: Evidence for two mechanisms of depolarization associated with a1-adrenoceptor activation in the rat anococcygeous muscle. Br J Pharmacol 86, 711 - 721 (1995)

30 Large WA: The effect of chloride removal on the responses of the isolated rat anococcygeus muscle to alpha1-adrenoceptor stimulation. J Physiol (Lond) 352, 17 - 29 (1994)

31 Gokina NI and Bevan JA: Role of intracellular $\mathrm{Ca}^{2+}$ release in histamine-induced depolarization in rabbit middle cerebral artery. Am J Physiol 278, H2105 - H2114 (2000)

32 Hogg RC, Wang Q and Large WA: Effects of $\mathrm{Cl}$ channel blockers on Ca-activated chloride and potassium currents in smooth muscle cells from rabit portal vein. Br J Pharmacol 111, 1333 - 1341 (1994)

33 Issa NP and Hudspeth AJ: Clustering of $\mathrm{Ca}^{2+}$ channels and $\mathrm{Ca}^{2+}-$ activated $\mathrm{K}^{+}$channels at fluorescently labeled presynaptic active zones of hair cells. Proc Natl Acad Sci USA 91, $7578-7582$ (1994) 